\title{
CREATING A GLOBAL NETWORK OF ARMENIAN PSYCHOLOGISTS
}

Takooshian H. (Fordham University, New York City, USA) takoosh@aol.com

Kalayjian A. (Meaningful World, New York City, USA)

DrKalayjian@meaningfulworld.com

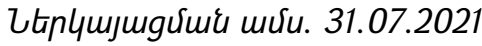

9pmpunuर्uir muरu. 10.08.2021

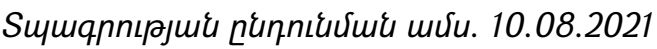

"Can we create a global network of Armenian psychologists?" This question arose in 2109 at the 100th anniversary conference at Yerevan State University. This three-part report details: (1) The challenge, (2) The current status of Armenians in psychological science and practice in the Republic, the USA, and elsewhere in the Diaspora. (3) Conclusion about the feasibility of a cross-national census of indigenous Armenians in psychology. Creation of the association of professional psychologists for the humanitarian mission "Psychology can withstand crises, disasters and wars."

Keywords: Armenians, Diaspora, psychology, behavioral science, history, development prospects.

DOI: https://doi.org/10.46991/SBMP/2021.4.2.330

"Can we create a global network of Armenian psychologists?" In 2019, this question resonated among 150 international participants at the historic 100th anniversary conference of psychology, hosted by Hrant Avanesyan at Yerevan State University. This is a three-part review of (1) The value and challenge of such a global network; (2) The current status of Armenians in psychological science and practice in the Republic, USA, and Diaspora; (3) Conclusions about the feasibility of such a global network.

1. The challenge. Over two-thirds of the world's 11 million Armenians live outside the Republic of Armenia today. The Armenians are an ancient people, with a Diaspora that goes back over 16 centuries, and local Armenian communities that span virtually all of the world's 193 major nations (Takooshian, 1987a). In whichever nation they are, Armenians are known for several features: industrious, educated, prosperous, loyal to their nation, religious, tight nuclear families, quick to acculturate, slow to assimilate (Takooshian, 1995). Armenians have made major contributions in many fields, including psychology.

Though we have little systematic demographic data on Armenians world-wide, anecdotal information indicates that Armenian psychologists have made seminal contributions to their field. As many agreed during the 2019 conference in Yerevan, 
the time has come to form a global network of Armenian scientists in general, and psychologists in particular. What is the current status of Armenians in the field of psychology?

2a. Republic. The roots of psychology in Armenia stretch back many centuries (Nalchajian \& Takooshian, 1997; Khudoyan et al., 2019). Psychological science in the Republic began in 1921 with the courageous work of martyred Dr. Gurgen M. Edilyan (1885-1942) of Yerevan State University (Jeshmaridian \& Takooshian). In 1956, after years of oppression, an Armenian branch of the Soviet Psychological Society was formed by Megerdich A. Mazmanian (1910-1977) and Hovsep Tutunjian (1918-1994) (Tutunjian, 1976; Pambookian, 1992; Takooshian, 1987c). Psychology in the Republic was impacted by the earthquake of 1988 (Gevorkyan et al., 2013), and the fall of the Soviet Union in 1991 (Nalchajian et al., 1997). In Armenia, from 1989 to 2003, the Federation of Sports Psychology of Armenia was active. (President: Hrant Avanesyan). A 1990 survey found 167 psychologists in 38 programs in the Republic (Vardanyan et al., 1990).

Since 2007, every 2 years the Department of General Psychology of YSU has been holding the International Conference "THE Current Issues in Theoretical and Applied Psychology"( http://psyarm.com/).

As of 2021, psychology in Armenia is a vibrant field, with increasing numbers of students, professionals, and programs. But in contrast to the Armenian Psychiatric Association (www.apnet.am/eng/1/Home.html), psychology in the Republic today lacks central coordination--a national association, conference, journal, or credentialing.

2b. USA. In the USA, the Armenian Behavioral Science Association (ABSA) was formed in New York City at 6 pm on August 31, 1987 (Toth, 1987)-founded by 6 diverse experts in six specialties (Takooshian, 1987b). "Right after the massive earthquake on 7 December 1988, ABSA quickly published its first Directory of 304 U.S. Armenian behavioral scientists in 1989, flagging 30 who were available for earthquake relief" (Takooshian, 2019, p. 384). Since 1987, ABSA identified over 750 U.S. behavioral scientists, about half of these in the field of psychology. "While the American Psychological Association recognizes 54 specialty divisions, about half of these specialties have been shaped by an Armenian-ancestry psychologist" (Takooshian, 2020, p. 8). This includes APA divisions: 1 GENERAL--Levon H. Melikian; 2 TEACHING--Seth Arsenian; 8 PERSONAITY--Albert Mehrabian; 14 INDUSTRIAL-ORGANIZATIONAL--Arthur G. Bedeian, Charles A. Pounian, Harold H. Kassarjian; 18 PUBLIC SERVICE--Bill Safarjan; 19 MILITARY--Jane Arabian; 20 AGING--Jane Mahakian; 26 HISTORY--William G. Sahakian; 36 RELIGION-Raymond F. Paloutzian; 39 PSYCHOANALYSIS--Hrair M. Babikian; 43 FAMILY-Harold Goolishian; 46 MEDIA--Mary Karapetian Alvord; 47 EXERCISE--John M. 
Basmajian; 49 GROUP THERAPY--Yvonne Agazarian; 53 CLINICAL CHILD-Susan J. Somonian; 56 TRAUMA--Ani Kalayjian” (Takooshian, 2020, p. 8).

Since 1987, ABSA has presented its "Outstanding Achievement Award" to 37 leaders in their specialty, during about 30 gatherings at APA or other regional or national conferences. About half of these awardees identify with their Armenian ancestry, and most see a connection between their ancestry and their career success. In 2019, Diaspora U.S. psychologist reached out to the Republic, to collaborate on such timely issues as dementia treatment and a suicide hot line (Kalayjian et al., 2019).

2c. Diaspora. Besides the USA, there are Diaspora Armenian communities across virtually all of the 193 nations in the United Nations. Though many of these are centuries-old, we have little systematic information on these communities. But thanks to the efforts of Hrant Avanesyan, Ani Kalayjian, and a few others, we know these communities contain some outstanding indigenous Armenian-ancestry psychologists who are leaders within their nation-in Russia, Latin America, Western and Eastern Europe.

3. Conclusions. Why and how can we form a global network of Armenian psychologists? The value of such a network is clear, as the beleaguered Republic seeks to reach out to Diaspora colleagues. New internet technologies today make the formation of this network more feasible than ever-to develop a strategy to identify, outreach, and engage Diaspora colleagues.

\section{References}

1. Avanesyan H.M. The development of Sport Psychology in Armenia (sources, development and the modern condition). Journal "Sport Psychologist”. Moscow. May, 2015.

2. Gevorgyan, S., Avetisian, M., \& Takooshian, H. Psychology in Armenia after the 1988 earthquake: 25 years later. International Psychology Bulletin, 17 (4), 2013, pp. 45-49.

3. Jeshmaridian, S.S., \& Takooshian, H. Country profile: Armenia. Psychology International, 5 (2), 1994, pp. 8-9.

4. Kalayjian A., Takooshian H., Mahakian J.L.,Kaftarian S. Symposium on Armenian behavioral sciences in the Diaspora," at the International Conference on Psychology, Yerevan State University. October, 2019.

5. Khudoyan, S., Gevorkyan, S., Karakashian, M., \& Takooshian, H. The development of psychological thought in Armenia. Presentation to the 2019 meetings of the American Psychological Association, Chicago, August 2019.

6. Nalchajian, A.A., \& Takooshian, H. The development of psychological thought in Armenia, Yerevan:Hogeban, 1997. 
7. Nalchajian, A.A., Jeshmaridian, S.S., \& Takooshian, H. Post-Soviet psychology: What is ahead? Eye on Psi Chi, 1 (3), 1997, Spring, pp. 22-24. https://doi.org/0033-2569.Eye1.3.22.

8. Pambookian H.S. Armenia. Pages 13-21 in V.S. Sexton and J.D. Hogan (Eds.), Psychology around the world (2 ed.). University of Nebraska Press, 1992.

9. Takooshian H. Armenian immigration to the United States from the Middle East. In R. Mirak (Ed.). Identity and assimilation: The Armenian experience in America (Special issue). Journal of Armenian Studies, 3, 1987, pp. 133155.

10. Takooshian H. (1987b). Armenian Behavioral Science Association inaugural meeting [A 90-minute DVD]

11. Takooshian H. (1987c). A census of psychologists in the Republic of Armenia, 1987. [A 90-minute DVD]

12. Takooshian H. Armenian Americans. In J. Galens, A.J. Sheets, \& R.V. Young (Eds.). Gale Encyclopedia of Multicultural America (pp. I:109-122). Detroit: Gale. https://www.everyculture.com/multi/A-Br/ArmenianAmericans.html, 1995.

13. Takooshian H. Invited address: The Armenian Behavioral Science Association, 30 years later. Pages 353-355 in H. Avanessyan (Ed.), Proceedings of the conference on 100 years of psychological science at Yerevan State University 2019, https://drive.google.com/file/d/1ay2ZgEmz7B9LKCM40iDvkJhkooel7Jh/view

14. Takooshian H. Armenian-Americans in the behavioral sciences. MIOPAP: Main Issues of Pedagogy \& Psychology, pages 7-9. https://miopap.aspu.am/index.php/miopap, 2020.

15. Toth V.A. Armenian Behavioral Science Association inaugural reception, [A 90-minute DVD], 1987.

16. Tutundjian H. Armenia. Pages 29-33 in V.S. Sexton \& H. Misiak (Eds.), Psychology around the world, 1976.

17. Vardanian G.A., Takooshian H., Karakashian M. (Eds.) Directory of psychologists in the Republic of Armenia (2 ed). New York: Armenian Behavioral Science Association, 1990. 